\title{
Lysis of Escherichia coli by Cloned $\phi$ X174 Gene $E$ Depends on its Expression
}

\author{
By U. BLÄSI, $\dagger$ B. HENRICH AND W. LUBITZ*† \\ FB Biologie, Universität Kaiserslautern, Postfach 3049, D-6750 Kaiserslautern, \\ Federal Republic of Germany
}

(Received 30 August 1984 ; revised 30 November 1984)

\begin{abstract}
The lysis gene $E$ of bacteriophage $\phi \mathrm{X} 174$ was cloned under transcriptional control of the lefthanded lambda promoter, giving rise to plasmid pSB12. Plasmid pSB22, identical to pSB12 except for an amber mutation in gene $E$, was constructed in the same way. Induction of the cloned wild-type gene by heat inactivation of the thermosensitive $\lambda$ cI857 repressor resulted in lysis of the host bacteria. With plasmid pSB22 only amber suppressor strains of Escherichia coli lysed after heat inactivation of $\lambda$ cI857. Lysis of $E$. coli was shown to depend on the rate of gene $E$ translation and on the growth phase of the bacteria. Stationary cells could not be lysed by the gene $E$ product $(\mathrm{gp} E)$, even if present in sufficient amounts to lyse growing cells. By isotopic labelling $\mathrm{gp} E$ could be detected among the proteins synthesized in normal $E$. coli as well as in minicells. Determination of gene $E$ expression suggested that $\mathrm{gp} E$ synthesis is translationally regulated.
\end{abstract}

\section{INTRODUCTION}

The essential role of the gene $E$ product $(\mathrm{gp} E)$ of bacteriophage $\phi \mathrm{X} 174$ in the lysis process after infection of Escherichia coli was first described by Hutchison \& Sinsheimer (1966). More recently, it has been shown that expression of cloned gene $E$ is sufficient to cause lysis of $E$. coli (Henrich et al., 1982a; Young \& Young, 1982). From the nucleotide sequence it was determined that $\mathrm{gp} E$ consists of 91 amino acids and has a molecular mass of about $10 \mathrm{kDal}$ (Barrell et al., 1976; Pollock et al., 1978). gpE seems to be devoid of enzyme activity (Eigner et al., 1963; Markert \& Zillig, 1965; Denhardt \& Sinsheimer, 1965) and its lytic function requires a functional autolytic system of the host cell (Lubitz et al., 1984a, b). This system is probably activated by integration of $\mathrm{gp} E$ into the cytoplasmic membrane of $E$. coli (Bläsi et al., 1983).

Hitherto, $\mathrm{gp} E$ has only been detected by expression of cloned $\mathrm{gp} E$ in minicells (Bläsi et al., 1983) or in heavily UV-irradiated $\phi X 174$-infected cells (Pollock et al., 1978). It has been estimated that roughly 100 to 300 molecules of $\mathrm{gp} E$ are made in a single cell after infection with $\phi \mathrm{X} 174$ (Pollock et al., 1978). If such a small number of molecules are sufficient to cause lysis of $E$. coli, then expression of gene $E$ must be highly regulated, taking into account that it is part of all major transcripts of the $\phi \times 174$ genome (Hayashi et al., 1981).

We have recently cloned a 1007 bp AluI fragment of $\phi$ XRF DNA under the control of the lac promoter (Henrich et al., 1982a). With this system, lysis of $E$. coli occurs within 20 to $120 \mathrm{~min}$ after induction of the lac promoter, depending on the amount of inducer used and on the intracellular concentration of lac repressor (Henrich et al., 1983). In this communication we describe the cloning of the same fragment of $\phi X 174$ DNA under the control of $\lambda p_{L}$. mRNA initiation at $\lambda \mathrm{p}_{\mathrm{L}}$ by inactivation of the thermosensitive $c I$ repressor led to lysis of $E$. coli strains which harbour the newly constructed plasmid pSB12 within 10 min after temperature shift.

† Present address: Institute of Genetics, University of Munich, Maria-Ward-Str. 1a, D-8000 München 19, FRG.

Abbretiations: am, amber; $\mathrm{gp} E$, gene $E$ product; $\lambda \mathrm{p}_{\mathrm{L}}$, lefthanded $\lambda$ promoter. 
With this system $\mathrm{gp} E$ could be detected in normal cells without any reduction in host protein synthesis. Synthesis of $\mathrm{gp} E$, however, is much less efficient than the expression of other proteins which are also encoded by $\mathrm{pSB} 12$.

\section{METHODS}

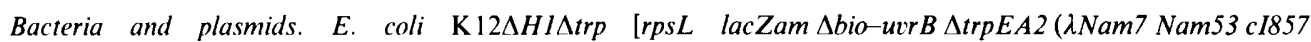
$\Lambda H I)]$ and plasmids pLc236 and pcI857 were kindly provided by E. Remaut, University of Gent, Belgium. E. coli HF4714 (Pro- Arg $^{-} \mathrm{Leu}^{-} \mathrm{Thi}^{-} \mathrm{Thy}^{-} \mathrm{Thr}^{-} \mathrm{Su}^{+}$) was from our strain collection. E. coli CSR603 $\left(\mathrm{F}^{-} \lambda^{-} \mathrm{Thr}^{-}\right.$leuB proA argE $\mathrm{Thi}^{-} \mathrm{Ara}^{-}$lac $Y \mathrm{Mtl}^{-}$galK Xyl- $g y r A \mathrm{Tsx}^{-} \operatorname{supE} \mathrm{Phr}^{-}$rec $A$ uvrA rpsL) was obtained from M. Jackson, University of Leicester, UK. E. coli DS410 (Thr ${ }^{-} \mathrm{Ara}^{-} \mathrm{Leu}^{-} \mathrm{Azi}^{\mathrm{r}} \operatorname{ton} A$ lac $Y$ gal $\lambda^{-} \min A \min B$ mal $A \mathrm{Xyl}^{-} \mathrm{Mtl}^{-} \mathrm{Thi}^{-} \mathrm{rec} A$ ) was obtained from W. Klipp, University of Bielefeld, FRG.

Media. Cells were grown in LB medium containing $\left(1^{-1}\right): 10 \mathrm{~g}$ tryptone, $5 \mathrm{~g}$ yeast extract and $5 \mathrm{~g} \mathrm{NaCl}$. Ampicillin was added to liquid and solid media to give a final concentration of $200 \mu \mathrm{g} \mathrm{ml}^{-1}$.

Recombinant DNA techniques. Preparation of plasmid DNA, transformation, isolation of DNA fragments and electrophoresis of DNA were done as described previously (Henrich et al., 1982a,b).

SDS-polyacrylamide gel electrophoresis. Polypeptides were separated by electrophoresis for $12 \mathrm{~h}$ at $150 \mathrm{~V}$ on $14-$ $20 \%$ polyacrylamide SDS gels using the discontinuous buffer system of Laemmli (1970). After electrophoresis the gels were processed for fluorography and exposed to Kodak X-ray film (RP-X-Omat) as described by Bonner \& Laskey (1974).

Protein labelling in transformed cells. Proteins were labelled with $\left[{ }^{35} S\right]$ methionine as described by Reeve (1981).

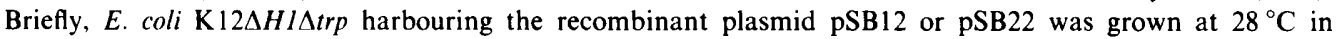
supplemented minimal medium to a density of $2 \times 10^{8}$ cells $\mathrm{ml}^{-1}$ and then shifted to $42^{\circ} \mathrm{C}$. At various times after the temperature upshift $150 \mu \mathrm{l}$ samples were taken and transferred to tubes containing $10 \mu \mathrm{Ci}\left[{ }^{35} \mathrm{~S}\right] \mathrm{methionine}$ $\left(1200 \mathrm{Ci} \mathrm{mmol}^{-1} ; 44.4 \mathrm{TBq} \mathrm{mmol}{ }^{-1}\right)$ and further incubated for $2 \mathrm{~min}$ at $42^{\circ} \mathrm{C}$. After labelling, the cells were immediately centrifuged and resuspended in $24 \mu \mathrm{l}$ sample buffer. The cells were disrupted by boiling for $5 \mathrm{~min}$ and analysed directly on a $14-20 \%$ polyacrylamide SDS gel.

Preparation of minicells and labelling of proteins. Minicells were prepared from $E$. coli DS410 grown in LB medium at $37^{\circ} \mathrm{C}$. Minicells were separated from nucleate cells by the use of sucrose gradients as described by Reeve $(1979,1981)$.

Minicells were resuspended in $\mathrm{M} 9$ medium (Miller 1972), containing $10^{-3} \mathrm{M}-\mathrm{MgSO}_{4}, 0 \cdot 2 \%$ glucose and $20 \mu \mathrm{g} \mathrm{D-}$ cycloserine $\mathrm{ml}^{-1}$, to give a density of $2 \times 10^{10}$ cells ml$^{-1}$. Then $0.5 \mathrm{ml}$ of the minicell suspension was added to $0.15 \mathrm{ml}$ methionine assay medium containing $10 \mu \mathrm{Ci}\left[{ }^{35} \mathrm{~S}\right]$ methionine $\left(1200 \mathrm{Ci} \mathrm{mmol}^{-1}\right)$ and incubated for $45 \mathrm{~min}$ at $37^{\circ} \mathrm{C}$. The minicells were collected by centrifugation, resuspended in $50 \mu \mathrm{l}$ sample buffer and processed as described above.

Enzymes and chemicals. Restriction endonucleases Eco RI and TaqI, and $\mathrm{T}_{4} \mathrm{DNA}_{\mathrm{N}}$ ligase and DNA polymerase (large fragment) were purchased from Boehringer-Mannheim. Ampicillin and lysozyme were from Sigma. SeaKem ME agarose was from FMC Corporation, Rockland, Maine, USA, $\left[{ }^{35}\right.$ S $]$ methionine from Amersham, and methionine assay medium from Difco.

\section{RESULTS AND DISCUSSION}

\section{Construction of plasmids $p S B 12$ and $p S B 22$}

In addition to a series of plasmids carrying the $\phi \times 174$ gene $E$ under the control of the lac promoter-operator region (Henrich et al., 1982a, 1983), we have cloned gene $E$ into plasmid PLc236 (Remaut et al., 1981) under the control of the $\lambda \mathrm{p}_{\mathrm{L}}$ promoter. For this purpose the EcoRI fragments of plasmids pUH12 and pUH22, carrying the $\phi \mathrm{X} 174$ gene $E$ in its wild-type form (lysis positive) or with the am 3 mutation (lysis negative) respectively (Henrich et al., 1982a), were isolated and inserted into the EcoRI site of plasmid PLc236 (Fig. 1). The ligation mixtures were used to transform $E$. coli $\mathrm{K} 12 \Delta H I \Delta t r p$, which harbours a defective, nonexcisable $\lambda$ prophage carrying the $\mathrm{cI}$ gene that codes for a temperature-sensitive repressor ( $c$ I857). Transformants were selected on plates containing ampicillin. After the isolation of plasmid DNA from several colonies, $20 \%$ were found to contain plasmids with the expected hybrid size. Digestion of these new plasmids with EcoRI produced two fragments, representing the original cloning vector PLc236 and the 1011 bp $\phi$ X174 EcoRI fragment from plasmid pUH12 or pUH22. The orientations of the cloned $\phi \times 174$ fragment in the recombinant plasmids pSB12 (gene $E$ wild-type allele) and pSB22 (gene $E$ am 3 allele) were determined by TaqI digestion. The restriction patterns obtained showed that both plasmids contain the inserted DNA fragment in the orientation which allows transcriptional control of the gene $E$ sequence by $\lambda \mathrm{p}_{\mathrm{L}}$. 
however, that the lytic process, once initiated, does not depend on further supply of $\mathrm{gp} E$ (Henrich et al., 1982a), seems not to hold in this case. It is more likely that gp $E$ not only activates the autolytic enzyme system at limited and distinct sites (Denhardt \& Sinsheimer, 1965; Markert \& Zillig, 1965) but also causes a concentration-dependent damage of the cell envelope.

\section{Influence of the growth phase of E. coli on the lytic action of $g p E$}

As observed by Denhardt \& Sinsheimer (1965) and Lubitz et al. (1984a), $\phi$ X174 only lyses $E$. coli cells which are actively growing. In accordance with this observation, cultures of strain $\mathrm{K} 12 \Delta H 1 \Delta t r p(\mathrm{pSB} 12)$ entering the stationary growth phase cannot be lysed by temperature upshift to $42^{\circ} \mathrm{C}$. The question of whether this is a consequence of a lack of transcription and/or translation of gene $E$ was investigated by shifting a culture of $E$. coli $\mathrm{K} 12 \Delta H 1 \Delta \operatorname{trp}(\mathrm{pSB} 12)$ in the stationary growth phase to $42^{\circ} \mathrm{C}$ for various periods, followed by reincubation at $28^{\circ} \mathrm{C}$. Lysis was not observed either during prolonged incubation at $42^{\circ} \mathrm{C}$ or during the reincubation at $28^{\circ} \mathrm{C}$. However, when such a culture after adjustment of the temperature at $28^{\circ} \mathrm{C}$ was diluted with fresh medium to half its density, the bacteria lysed even in the presence of rifampicin and chloramphenicol (Fig. 3). This indicates that neither transcription nor translation of $\mathrm{gp} E$ is inhibited in stationary cells. The block which hinders the action of $\mathrm{gp} E$ as a lysis protein is coupled with stagnation of growth of the cells, most probably with the regulation of the autolytic system (Lubitz et al., 1984a, b). Stationary cultures of $E$. coli $\mathrm{K} 12 \Delta H 1 \Delta \operatorname{trp}(\mathrm{pSB} 12)$ which had been kept at $42^{\circ} \mathrm{C}$ for up to several hours in the presence of $\mathrm{gp} E$ lysed after a signal which is coupled to onset of growth when they were diluted and reincubated at $28{ }^{\circ} \mathrm{C}$.

\section{Identification of $g p E$}

The gene $E$ product of $\phi X 174$ was first identified by Pollock et al. (1978) in heavily UVirradiated $E$. coli cells. However, at the position where $\mathrm{gp} E$ migrated in the SDS gel used, other host cell proteins were also visible. Using plasmid $\mathrm{pSB} 12$, it was possible to detect $\mathrm{gp} E$ by separation of total cell proteins (Fig. 4). At a position which corresponds to a molecular mass of $10 \mathrm{kDal}$, an additional band is visible in the protein pattern of pSB12 transformants which is absent from the pattern of bacteria carrying pSB22. Pulse labelling further revealed that $\mathrm{gp} E$ is made throughout the period of induction, between temperature upshift and the onset of lysis (Fig. 4). The latent period between induction and lysis was prolonged by incubating the cells in minimal medium instead of rich medium. Under these conditions of reduced growth, a labelling period of $2 \mathrm{~min}$ with $\left[{ }^{35} \mathrm{~S}\right]$ methionine was sufficient to detect $\mathrm{gp} E$. Because other attempts to visualize $\mathrm{gp} E$ in untreated bacteria have so far failed, it was of interest to determine the quantities in which $\mathrm{gp} E$ is synthesized relative to other proteins encoded by plasmid pSB12.

\section{Estimation of gpE synthesis in pSB12 transformants}

In order to reduce the amount of labelled host proteins, minicells were used. The amount of $\mathrm{gp} E$ formed relative to other plasmid-encoded proteins could be estimated by comparison of the protein patterns of minicells carrying $\mathrm{pSB} 12$ or $\mathrm{pSB} 22$, respectively.

To prevent expression of the cloned $\phi \mathrm{X} 174$ lysis gene at $28^{\circ} \mathrm{C}$, the minicell-producing strain was first transformed with plasmid pcI857 encoding the thermosensitive $\lambda \mathrm{cI}$ repressor (Remaut et al., 1983). As shown in Fig. 5(a), a distinct band of $\mathrm{gp} E$ can be identified among the pSB12 encoded proteins when compared to the protein pattern of pSB22-transformed minicells. The corresponding $\mathrm{gp} E$ peak is also clearly visible in a density scan of the autoradiogram (Fig. $5 b$ ). The amount of $\mathrm{gp} E$ which accumulated during the labelling period of $45 \mathrm{~min}$ corresponds, however, only to $2 \cdot 7 \%$ of the total of labelled proteins.

Under conditions where the $\beta$-lactamase gene had been cloned under control of $\lambda \mathrm{p}_{\mathrm{L}}$, expression of $\beta$-lactamase accounted for $30 \%$ of de novo protein synthesis in normal cells (Remaut et al., 1981). However, in such cells, in contrast to minicells, $\mathrm{gp} E$ represents only a minor protein (Fig. 4). The relatively low rate of $\mathrm{gp} E$ synthesis may thus be due to less efficient translation rather than to ineffective transcription.

As can be deduced from the nucleotide sequence of bacteriophage $\lambda$ (Sanger et al., 1982) and the cloned fragment of $\phi$ X174 DNA, plasmid pSB12 contains no other genes between $\lambda \mathrm{p}_{\mathrm{L}}$ and 


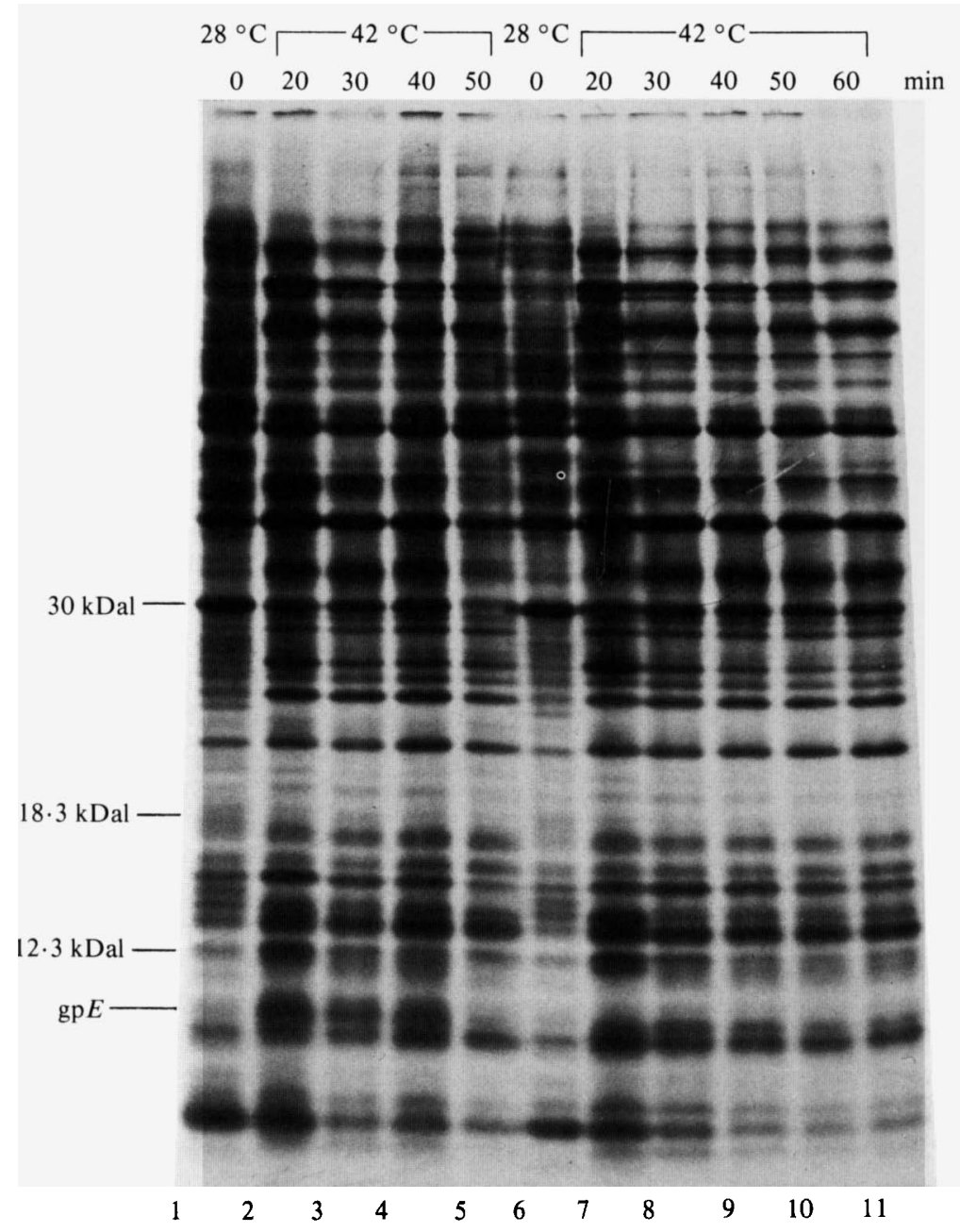

Fig. 4. Synthesis of $\mathrm{gp} E$ in $E$. coli $\mathrm{K} 12 \Delta H 1 \Delta t r p$. Proteins synthesized in bacteria harbouring the recombinant plasmids pSB12 (lanes $1-5$ ) or pSB22 (lanes 6-11) were labelled with [ ${ }^{35}$ S]methionine and separated by electrophoresis on a $14-20 \%$ polyacrylamide SDS gel. The starting times of the labelling periods and the incubation temperatures are given at the top of the figure. The molecular masses of some protein markers, and the position of $\mathrm{gp} E$, are indicated on the left.

gene $E$. The gene $E$ ribosome-binding site is the first one on the mRNA which is initiated at $\lambda \mathrm{p}_{\mathrm{L}}$. However, translation of $\mathrm{gp} E$ seems to be poor. The relatively small amount found even after prolonged time of induction cannot be due to rapid degradation because, as shown above, $\mathrm{gp} E$ seems to be quite stable. Therefore other factors should be responsible for its low rate of synthesis. The ribosome-binding site of gene $E$ contains only 4 bp which match the ShineDalgarno sequence (Barrell et al., 1976). In addition, there is the possibility of some kind of translational attenuation because of the occurrence of 21 leucine residues within the 91 amino acids sequence of $\mathrm{gp} E$, including one stretch of 7 leucines interrupted by one serine (Barrell et al., 1976). More important, however, with respect to gene $E$ expressivity, could be the codon usage in gene $E$. Many codons of gene $E$, including almost two-thirds of the leucine codons, correspond to minor tRNA species (Grantham et al., 1980; Gouy \& Gautier, 1982) and thus translation efficiency of the lethal $\mathrm{gp} E$ seems to be highly modulated. In addition, a perfect hairpin of $7 \mathrm{bp}$ in the C-terminal coding region of gene $E$ (Müller \& Fitch, 1982) could exert severe influences on the rate of $\mathrm{gp} E$ formation. 

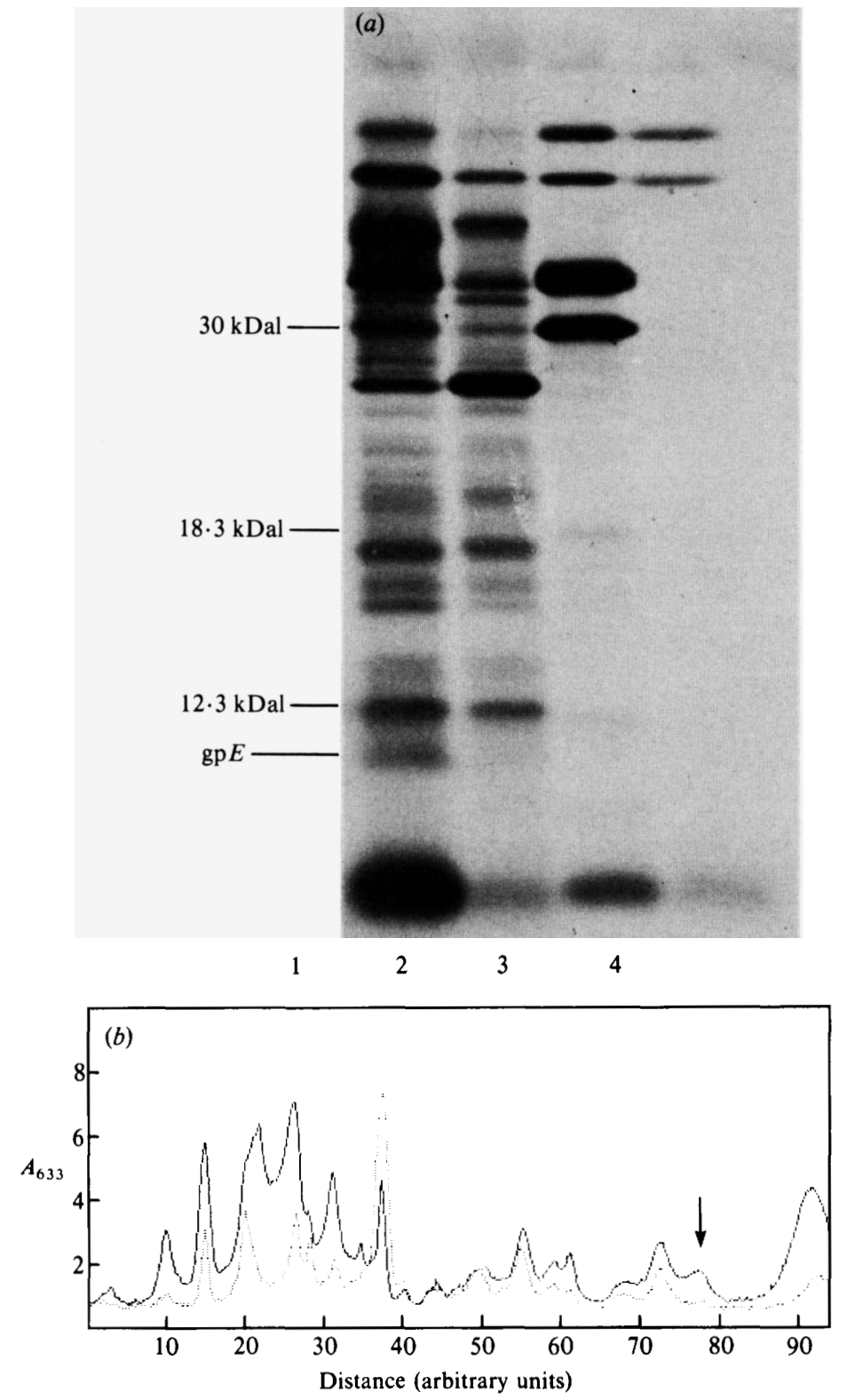

Fig. 5. Synthesis of gp $E$ in minicells. (a) Polypeptides synthesized in minicells of E. coli DS410 (recA) harbouring pSB12 and pcI857 (lane 1), pSB22 and pcI857 (lane 2), pcI857 (lane 3), and no plasmids (lane 4) were labelled with $\left[{ }^{35} \mathrm{~S}\right]$ methionine and separated on a $14-20 \%$ polyacrylamide SDS gel. The molecular masses of protein markers, and the position of $\mathrm{gp} E$, are indicated on the left. $(b)$ Density scan of the autoradiogram shown in $(a)$. $|1| 1 \mid$, Scan of the DS410(pSB12, pcl857) protein pattern; ..., scan of the $\mathrm{DS} 410(\mathrm{pSB} 22$, pcl857) protein pattern. The position of $\mathrm{gp} E$ is indicated by an arrow.

We thank all who have provided us with bacterial strains and plasmids. This work was supported by a grant from the Deutsche Forschungsgemeinschaft (Lu 213/4-2).

\section{REFERENCES}

Barrell, B. G., Air, G. M. \& Hutchison, C. A. Bläsi, U., Geisen, R., Lubitz, W., Henrich, B. \& (1976). Overlapping genes in bacteriophage $\phi \times 174$. Nature, London 264, 34-41. PLAPP, R. (1983). Localisation of the bacteriophage $\phi \times 174$ lysis gene product in the cell envelope of 
Escherichia coli. In The Target of Penicillin, pp. 205210. Edited by R. Hakenbeck, J.-V. Höltje \& H. Labischinski. Berlin \& New York: de Gruyters.

Bonner, M. \& Laskey, R. (1974). Detection method for tritium labelled proteins and nucleic acids in polyacrylamide gels. European Journal of Biochemistry 45, 433-449.

DenhardT, D. T. \& Sinsheimer, R. L. (1965). The process of infection with bacteriophage $\phi \times 174$. III. Phage maturation and lysis after synchronized infection. Journal of Molecular Biology 12, 641-646.

Eigner, J., Stouthamer, A. H., Van Der Sluys, I. \& COHEN, J. A. (1963). A study of the 70 S component of bacteriophage $\phi \times 174$. Journal of Molecular Bio$\log y$ 6, 61-84.

Gouy, M. \& Gautier, C. (1982). Codon usage in bacteria : correlation with gene expressivity. Nucleic Acids Research 10, 7055-7074.

Grantham, R., Gautier, C. \& Gouy, M. (1980). Codon frequencies in 119 individual genes confirm consistent choices of degenerate bases according to genome type. Nucleic Acids Research 8, 1893-1912.

HAYASHI, M. N., HAYAShI, M. \& Imai, M. (1981). Bacteriophage $\phi \times 174$ - specific mRNA synthesis in cells deficient in termination factor rho activity. Journal of Virology 38, 198-207.

HenRICH, B., Lubitz, W. \& PlapP, R. (1982a). Lysis of Escherichia coli by induction of cloned $\phi \times 174$ genes. Molecular and General Genetics 185, 493-497.

HeNRICH, B., LubITZ, W. \& Fuchs, E. (1982b). Use of benzoylated-naphthoylated DEAE-cellulose to purify and concentrate DNA eluted from agarose gels. Journal of Biochemical and Biophysical Methods 6, 149-157.

Henrich, H., Lubitz, W. \& Plapp, R. (1983). Expression of $\phi \times 174$ lysis gene cloned into different plasmids. In The Target of Penicillin, pp. 197-203. Edited by R. Hakenbeck, J.-V. Höltje \& H. Labischinski. Berlin \& New York: de Gruyters.

Hopp, T. D. \& Woods, K. R. (1981). Prediction of protein antigenic determinants from amino acid sequences. Proceedings of the National Academy of Sciences of the United States of America 78, 38243828.

Hutchison, C. A., III \& Sinsheimer, R. L. (1966). The process of infection with bacteriophage $\phi \mathrm{X} 174$. X. Mutations in a $\phi \mathrm{X}$ lysis gene. Journal of Molecular Biology 18, 429-447.

Inokuchi, H., Yamao, F., Sakano, H. \& Ozeki, H. (1979). Identification of transfer RNA suppressors in Escherichia coli. I. Amber suppressor $\mathrm{su}^{+2}$, an anticodon mutant of tRNA 2 Gin. Journal of Molecular Biology 132, 649-662.

LAEMMLI, U. K. (1970). Cleavage of structural proteins during assembly of the head of bacteriophage T4. Nature, London 227, 680-685.

Lubitz, W., Halfmann, G. \& Plapp, R. (1984a). Lysis of Escherichia coli after infection with $\phi \times 174$ depends on the regulation of the cellular autolytic system. Journal of General Microbiology 130, 10791087.

Lubitz, W., HaRkness, R. \& Ishiguro, E. E. (1984b) Requirement for a functional host cell autolytic enzyme system for lysis of Escherichia coli by bacteriophage $\phi \times 174$. Journal of Bacteriology 159, 385-387.

MARKERT, A. \& Zillig, W. (1965). Studies on the lysis of Escherichia coli by bacteriophage $\phi \times 174$. Virology 25, 88-97.

MILlER, J. H. (1972). Experiments in Molecular Genetics: Cold Spring Harbor, New York: Cold Spring Harbor Laboratory.

MÜLLER, R. U. \& FiTCH, W. M. (1982). Evolutionary selection for perfect hairpin structures in viral DNAs. Nature, London 298, 582-585.

Pollock, T. J., Tessman, E. S. \& Tessman, J. (1978). Identification of lysis protein $\mathrm{E}$ of bacteriophage $\phi X 174$. Journal of Virology 28, 408-410.

REEVE, J. (1979). Use of minicells for bacteriophagedirected polypeptide synthesis. Methods in Enzymo$\log y$ 68, 493-503.

REEVE, J. (1981). $\phi$ X174-directed DNA and protein synthesis in infected minicells. Journal of Virology 40, 396-402.

Remaut, E., Staussens, P. \& Fiers, W. (1981) Plasmid vectors for high-efficiency expression con trolled by the $\mathrm{p}_{\mathrm{t}}$. promoter of coliphage lambda. Gent 15, 81-93.

Remaut, E., Tsav, H. \& Fiers, W. (1983). Improvec plasmid vectors with a thermoinducible expressior and temperature-regulated runaway replication Gene 22, 103-113.

Sanger, F., Coulson, A. R., Hong, G. F., Hill, D. F \& Petersen, G. B. (1982). Nucleotide sequence o bacteriophage $\lambda$ DNA. Journal of Molecular Biolog. 162, 729-773.

YounG, K. D. \& Young, R. (1982). Lytic action o cloned $\phi$ X174 gene E. Journal of Virology 44, 993 1002. 